\title{
Group for family/caregivers of elderly with Alzheimer's: experience of teachers based on the complexity
}

\author{
Grupo para familiares/cuidadores de idosos com Alzheimer: vivência de docentes à luz da \\ complexidade
}
Grupo de familiares/cuidadores de ancianos con Alzheimer: experiencia de profesores a la luz de la complejidad

Silomar Ilha ${ }^{1}$, Dirce Stein Backes $^{1}$, Silvana Sidney Costa Santos ${ }^{1}$, Daiane Porto Gautério-Abreu ${ }^{1}$, Claudia

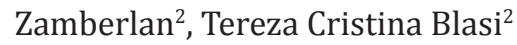

Objective: to understand the relationships experienced by a group of health care teachers directed to family members/ caregivers of older people with Alzheimer's disease. Methods: qualitative research, conducted with five teachers participating in a support group developed in a university. Data collected by the technique of focus group submitted to Focal Strategic Analysis. Results: six categories were identified: Difficulty in raising awareness of the participants about Alzheimer's disease; The interdisciplinary in the guidelines; Exchange of knowledge; Acquire/search for more knowledge; Expansion/socialization of knowledge about Alzheimer's disease: an even existing challenge; Absence attendance: a threat to the existence of the group. Conclusion: the disorder is a reality experienced by teachers in the group, which is (re) organize constantly seeking the best way to guide and foster care.

Descriptors: Alzheimer Disease; Social Support; Nonlinear Dynamics; Health Personnel; Faculty, Nursing.

Objetivo: compreender as relações vivenciadas por um grupo de docentes da área da saúde direcionadas aos familiares/ cuidadores de pessoas idosas com doença de Alzheimer. Métodos: pesquisa qualitativa, realizada com cinco docentes participantes de um grupo de apoio desenvolvido em uma instituição universitária. Dados coletados pela técnica de Grupo Focal, submetidos à Análise Focal Estratégica. Resultados: identificaram-se seis categorias: Dificuldade na sensibilização dos participantes acerca da doença de Alzheimer; A interdisciplinaridade nas orientações; Troca de conhecimento; Adquirir/ buscar mais conhecimento; Expansão/socialização do conhecimento sobre a doença de Alzheimer: um desafio ainda existente; Ausência de assiduidade: uma ameaça à existência do grupo. Conclusão: a desordem é uma realidade vivenciada pelos docentes no grupo, que se (re)organizam constantemente em busca da melhor forma de orientar e promover cuidados. Descritores: Doença de Alzheimer; Apoio Social; Dinâmica não Linear; Pessoal de Saúde; Docentes de Enfermagem.

Objetivo: comprender las relaciones experimentadas por un grupo de profesores del área de atención a la salud dirigidas a familiares/cuidadores de ancianos con enfermedad de Alzheimer. Métodos: investigación cualitativa, con cinco profesores participantes de un grupo de apoyo desarrollado en una universidad. Datos recolectados mediante la técnica de grupo focal sometidos a Análisis Estratégico focal. Resultados: se identificaron seis categorías: Dificultad en la sensibilización de los participantes acerca de la enfermedad de Alzheimer; Interdisciplinariedad en las directrices; Intercambio de conocimientos; Adquirir/buscar más conocimiento; Expansión/socialización del conocimiento sobre la enfermedad de Alzheimer: un reto aún existente; Ausencia de asiduidad: una amenaza para la existencia del grupo. Conclusión: el trastorno es una realidad experimentada por profesores en el grupo, que se (re)organizar constantemente en búsqueda de la mejor manera de orientar y promover atención.

Descriptores: Enfermedad de Alzheimer; Apoyo Social; Dinámicas no Lineales; Personal de Salud; Docentes de Enfermería.

\footnotetext{
${ }^{1}$ Universidade Federal do Rio Grande. Rio Grande, RS, Brazil.

${ }^{2}$ Centro Universitário Franciscano. Santa Maria, RS, Brazil.

Corresponding author: Silomar Ilha

Rua General Osório S/n Campus da Saúde, Escola de Enfermagem, CEP: 96.201-900. Rio Grande, RS, Brazil. E-mail: silo_sm@hotmail.com
} 


\section{Introduction}

Population aging is a conquest of humanity and allow greater interaction of the elderly in families ${ }^{(1)}$. However, when aging, the human being is more likely to become dependent. For this reason, it is possible to observe in recent years a progressive increase of families in the care of an elderly person in dependency condition, caused mainly by dementia processes, such as Alzheimer's disease ${ }^{(2)}$.

Alzheimer's disease has a slow and insidious onset, with a clinical picture that varies from person to person, taking place in three stages, leading the elderly person to have from mild forgetfulness to a total restriction to be in bed. As the disease progresses, it increases the demand for care, requiring constant supervision $^{(3)}$. In Brazil, the care for the elderly with Alzheimer's disease are performed most of the time by a family member at home ${ }^{(4)}$.

The continuous care to an elderly person with Alzheimer's disease, leads the family caregiver to experience significant changes in their social, financial, emotional and family routine ${ }^{(3)}$. Such changes lead to a decline in the family's quality of life directly involved in the care ${ }^{(5)}$. When recognizing the complexity that the context experienced involves through Alzheimer's disease, it is clear that care needs to be performed by various healthcare professionals ${ }^{(6)}$.

Realizing the reality experienced by these families, some professionals and health/teaching institutions have invested efforts in care and advice with the creation of support groups for family members/caregivers of older people with Alzheimer's disease. These professional groups of one or more subjects in the health and human areas meet with family members/caregivers by providing them with guidance on the disease and care for the elderly as much for their self-care. Thus, the importance of the experience of health care professionals need to be prepared to work in different sectors and activities that address the health of older people with Alzheimer's/ families and community is emphasized ${ }^{(7)}$.
Some studies have been demonstrating the difficulties faced by caregivers of elderly with Alzheimer's disease ${ }^{(2,8-9)}$. However, there is a gap of knowledge from the perspective of health professionals working with the elderly/family. Thus, it is considered important to investigate the perception of these professionals about the experiences in the group, seeking to understand the possible difficulties, strengths, opportunities and challenges experienced. Thus, justifying the need and relevance of this study, which can serve as guidance for other professionals willing to develop similar activities.

In addition, it is relevant to enlarge and discuss this process under new standards, using the complexity ${ }^{(10)}$ of Edgar Morin. The experienced processes (re)think, using extended reference, allows professionals, members of the group, planning complex actions towards a systemic and consistent care to the individual needs defined in this study as the elderly person with Alzheimer's disease and their family caregivers, and the whole, that is the family, as complex unit and its network of systemic relationships, which includes the support group.

Based on these, the question is: what are the relationships, interactions and associations experienced by a group of health care teachers in the care of family/caregivers of elderly with Alzheimer's disease? In an attempt to answer the question, the aim of the study is to understand the relationships experienced by a group of health care teachers directed to family caregivers of elderly with Alzheimer's disease.

\section{Method}

Qualitative research with theoretical reference about the complexity, which guided the researcher and the researched to reflect on new ways to articulate the uncertainties and disorders to new ways to (re)create the methods for understanding the phenomenon ${ }^{(10)}$.

The study was conducted with five teachers of health area courses participating in the University Extension Project, developed in the form of support 
to family group caregivers of people with Alzheimer's disease, active since 2007 and developed into a higher education institution in the state of Rio Grande do Sul, Brazil. A multidisciplinary team, consisting of teachers and students of Nursing, Pharmacy, Physiotherapy, Nutrition, Dentistry, Psychology and Occupational Therapy, develops this project. In one of the group meetings, the members were invited to participate. Inclusion criteria were: teaching of health care courses and actively participating in the project for at least six months. Teachers excluded were because for some reason, they were removed from the group, participating in the group less than six months or they were not in the health area.

Data were collected through the Focus Group technique, which is characterized as a group that meets to discuss about a particular topic, in common to the participants. The choice of this data collection technique was due to its ability to promote horizontalized group interaction among participants, which allowed them to explore and expand the understanding about the phenomenon under investigation $^{(11)}$. Three meetings were held between June and August 2013, each lasting about 120 minutes.

In the first meeting, it was sought to understand the perception of teachers about the family (re)organization in the coping process of Alzheimer's disease. To this end, the moderator read a brief text taken from the book The well-made Head: to rethink the reform, to reform the thinking ${ }^{(12)}$. Next, the participants were invited to express/record in an A4 sheet of paper, the first idea that came to their minds when reflecting on Alzheimer's disease, and subsequently the family. As a result, each participant presented their ideas, which enabled intense group discussions, which were expanded gradually based on complex thinking.

At the second meeting, they resumed up some points discussed at the previous meeting and dialogued about the potential/strengths and frailties/ weaknesses experienced by the group in the care process to the relatives/caregivers of older people with Alzheimer's disease. They were invited to record on paper, through drawings, illustrations, written or any other way about the main potential/strengths that support the care process/living with family members/ caregivers and frailties/weaknesses found in the care process to family members/caregivers. Then, a news discussion from what each had recorded was held.

In the third meeting, the synthesis of previous meetings was held, and it continued expanding discussions on opportunities, challenges and threats encountered by teachers in the process of supporting the (re)organization of families of elderly people with Alzheimer's disease. While participants discussed these elements, the moderator noted some strong terms during the speeches, riding a little scheme. As result, the moderator presented to teachers the topics registered, questioning them about their agreement and acceptance and if they would like to add something. After the analysis, a complex structure was elaborated, involving elements discussed at the meeting, establishing some aspects of the Alzheimer's disease for care from the perspective of complexity.

Data analysis began with the collective summaries of each meeting. The theoretical analysis of the synthesis based on the complexity benchmark and a methodological analysis according to Focal Strategic Analysis were performed, which proposes a dynamic and cooperative participation of the research subjects $^{(13)}$. Nurses, suitable for data analysis of the Focus Group, proposed this analysis technique, aiming to expand the phenomenon under investigation ${ }^{(13)}$, in this case, the performance of teachers in the support group, from the collective deepening based on strengths and weaknesses as well as challenges, threats, opportunities and strategies related to personal and collective experiences.

Thus, the statements of the participants were recorded, transcribed and after showed by the group moderator to be analyzed collectively. In Strategic Focal Analysis, the data should be analyzed in the collective way, researcher and participating being actors and authors throughout the process. Thus, the process of collective analysis, occurred in three circular 
stages: first, the reports were read several times by the moderator aloud in the group, after participants were grouped into four phenomena by the moderator: 1- frailties and weaknesses; 2 - the potential or forces; 3 - opportunities; 4 - the challenges or threats ${ }^{(13)}$.

Later, a new collective reading of the group reports in each of the phenomena were performed, seeking to establish appropriate names or identities for each experienced situation with a view to emerging categories of analysis. Strategic Focal Analysis categories can arise from a number of reports that are similar or complementary, or even a single report, since it is intended to draw the group's collective and/or unique experiences to each participant ${ }^{(13)}$.

The ethical and legal research linked with human beings were considered, the participants signed the Informed Consent Form, in two copies, giving one for the participant and the other to the researcher. The local Ethics Committee in Research approved the study, by the opinion 092/2013. The anonymity of the participants was remained, identifying them by the letter T (teaching) followed by a number (T1, T2 ...T5).

\section{Results}

Of the five teachers, one was a nurse, one pharmacist, one physiotherapist and two nutritionists. The adopted method enabled to generate theoretical constructs that led to the delineation of six categories. One category was referring to the frailties and weaknesses: Difficulty in raising awareness of the participants about Alzheimer's disease. Two categories from the potential and strengths: The interdisciplinary in the guidelines; Knowledge exchange. One category related to opportunities: Acquire/search for more knowledge.

Regarding the challenges and threats, two categories emerged: Expansion/socialization of knowledge about Alzheimer's disease: an even existing challenge; Absence of attendance: a threat to the existence of the group. Figure 1 shows, schematically, the process of integration of the categories, based on the complexity of reference.

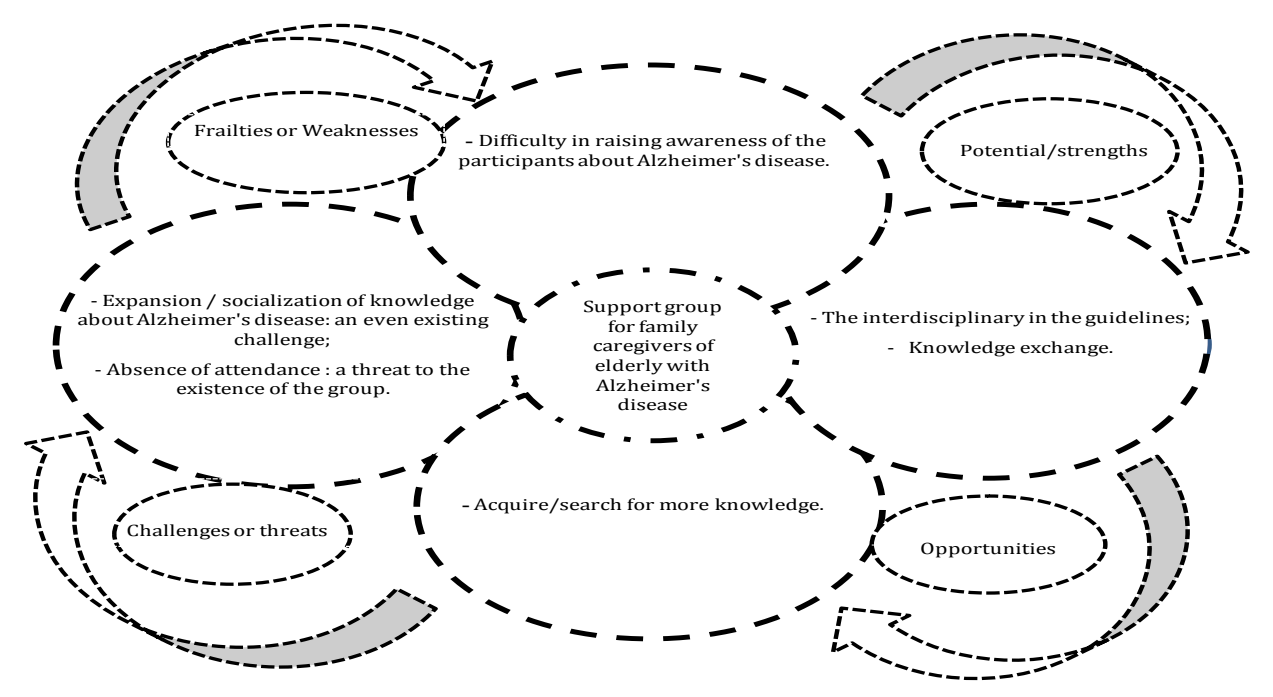

Figure 1 - Complex scheme of categories integration 


\section{Difficulty in raising awareness of the participants about Alzheimer's disease}

One of the weaknesses reported by teachers is about the difficulties they encounter in raising awareness about Alzheimer's disease to the participants, due to the ignorance of people about Alzheimer's disease and the lack of guidance from the family. This, according to participants, generates the distance, hindering the guidelines and the care process: People do not have a real sense of what illness means and what it entails and that creates a distance, hindering the guidelines... (T4). The lack of family guidance to know what to do or who to look for... this ends up being a barrier in the care process, until we can make people aware of how things should be done, how things will happen (T2). Alzheimer's disease often causes repudiation of the disease in society and the patient, which I believe to be related to lack of knowledge about the etiology, diagnosis and treatment (T1).

Another factor that hinders the process of teaching about Alzheimer's disease, reported by teachers, refers to non-acceptance of the disease by people. This process is enhanced by the difficulties encountered by the family who attends the group to pass on the knowledge gained to other family members who did not attend the meeting: I think it is often the non-acceptance of the disease. It is difficult to accept that a family has Alzheimer's. So, I think that family members come to the group, interact, absorb some information, but find it difficult to pass on information within the family, for the one who stayed home did not experience the group and the whole orientation process (T3). We have a prejudice of the disease and we do not understand how a person can lose both cognitive and especially their autonomy. It is very difficult to accept it (T1). In one teacher's speaking, there is the prejudice that exists around the disease that sometimes results from ignorance about it.

\section{The interdisciplinary in the guidelines}

Among the potential experienced by the group of teachers, there is the opportunity of interdisciplinary action, increasing integration of knowledge among teachers from different backgrounds and knowledge of family/caregivers: I think the main potential is the work that we develop together. When we were doing the specific guidelines of each individual course, I think it was very fragmented. When we started working together, we can realize that family caregivers have seen care differently... (T3). Integration of technical and practical knowledge, through the joint work of the different courses, professionals from different backgrounds, but also of family members and caregivers in their daily activities (T1). Here the group can develop what in other places, other spaces we cannot, that is to work in an interdisciplinary way. In other spaces it is only in theory (T4).

It is possible to see that other work attempts have been used in the group, with specific and fragmented guidelines. However, interdisciplinary came out of the theory and became part of the practice, being, according to participants, with the greatest potential to sensitize and guide the practice of family care.

\section{Knowledge exchange}

Another potential was the knowledge exchange between teachers and family caregivers, interconnection between scientific knowledge from the institution and the knowledge gained by relatives/ caregivers in the experience of care for the elderly with Alzheimer's disease: It's a two-way exchange, bilateral, because family caregivers have the daily experience and we have the knowledge based on the literature and which sometimes has to do with that experience, but there are things that escape from us as scientific knowledge... (T2). It is the exchange of knowledge itself, because who does not live with Alzheimer's disease on a daily basis have no idea what might happen. Then that look that we would not, would not take account professional practice if there were no interactions with family caregivers (T1). I think the most interesting group is the issue of uniqueness, exchanges of experiences there. I remember a family that had been in the group, receiving the information and say - I will try to do it with my mom! And the next meeting he always reported he had worked or not. So, these experiences are very positive in the group (T4).

There was the understanding of teachers about the limitations of knowledge and appreciation that they demonstrate the knowledge of family/caregivers, 
which retain the characteristic of two-way exchange of knowledge within the group.

\section{Acquire/search for more knowledge}

This category refers to opportunities by teachers to join the group, like knowledge about the disease, the link between theory and practice, building different view for the elderly person with Alzheimer's disease and caregiver in their various dimensions, among others: Knowledge of Alzheimer's disease. One thing is to have scientific knowledge about the disease in general and the other are the experiences, experiments and routine. Both practice and theory (T4). It allowed greater knowledge and with it, the development of a peculiar view at patients, but mostly on the caregiver, valuing his experience as an individual that promotes care in all its dimensions: technical, spiritual and emotional care (T1). The opportunity for greater insight into Alzheimer's disease, dealing, have contact with different realities, seek to know more about the disease, how it occurs and on top of that seek treatment strategies and the main forms of management... (T5).

There is the interest in knowing more, the pursuit of knowledge with a view to finding care and treatment strategies for the elderly with Alzheimer's disease and family/caregiver.

\section{Expansion/socialization of knowledge about Alzheimer's disease: an even existing challenge}

For teachers, a challenge even experienced in practice in the group is to increase the knowledge produced, in order to reach more people and families living in the context of Alzheimer's disease. In addition, it is necessary that this knowledge is extended to society as a whole, breaking remaining stigma and prejudice: To increase knowledge beyond the group to reach more people/families living with Alzheimer's disease, but still not attending the group (T4). Awareness of the issue of Alzheimer's and its importance within the family, social and health, and the importance of spreading knowledge beyond the group itself. That is, to society as a whole, needing to break away from the stigma of the disease that still generates a lot of prejudice (T1). I think it remains to reach people, to say how important this group is, as we are discussing here in this group, this exchange. I think reaching the caregiver for me is still a challenge, because there are few caregivers in the group yet (T2).

It was found that approaching the caregiver also presents a challenge and this reflected in the small number of caregivers who participate in the group compared to the number of people with Alzheimer's disease.

\section{Absence of attendance: a threat to the existence of the group}

The lack of attendance of family/caregivers in the group, according to teachers, is a threat to existence of the group, as this exists by and for them: A challenge I always tell in the meetings during the first semester is the difficulty to get a significant number of caregivers (T2). I think it really is a threat to the group infrequency or no continuity of caregivers in the group in this exchange process, to come, to receive and show their experiences, because this group is there for them, for them (T3). It can be observed the difficulty in constancy of family/caregivers in group activities. This issue is discussed from the beginning of the semester, when is the planning of the group's activities.

\section{Discussion}

As Alzheimer's disease is hardly perceived, by being a neurodegenerative condition, no effective therapy for all cases, the concept of complexity is also difficult concept. The word "complexity" is usually referred to when there is a problem, something complicated to solve.

It is clarified that in the reference perspective of complexity, used in this study, is something complex, when it has a multitude of interactions, associations and interfaces established between a large number of units, expressed by the various care and health dimensions ${ }^{(14)}$. Thus, the complex thought aspires to knowledge in their multiple dimensions, recognizing the principle of incompleteness and uncertainty, and 
presenting the recognition of the links between the entities that our thinking must necessarily distinguish, but not isolated from one another ${ }^{(12)}$.

With this uncertainty and incompleteness, the work of teachers of the support group for family/ caregivers of elderly with Alzheimer's disease is built. To understand care developed by the group of teachers to family members/caregivers of elderly people with Alzheimer's disease from the perspective of complexity thinking, more concerns emerged than answers, since this disease is even without a specific diagnosis without an effective therapy in all cases and its symptoms are extremely unique in each person.

Complexity thinking helps in understanding uncertainty, since it brings together, contextualize and globalize the phenomenon, while recognizing the individual, the singular and the concrete ${ }^{(15)}$. In this understanding, it is essential to recognize each family caregiver as a complex system through relationships and interactions that each person establishes. As family caregivers, it is part of a whole, which in this study can be thought of as family. At the same time, the family is also the whole thing, because it has other networks of relationships and systemic interactions. Thus, the whole is a complexity unit and cannot be reduced to the sum of the elements of the parties ${ }^{(10)}$.

Based on this thinking, it is sought to meet the multidimensionality of the participants through interdisciplinary work. Interdisciplinary was mentioned by teachers, participants in this study, as a potentiality, since it allows the integration of knowledge among teachers from different backgrounds and knowledge of family/caregivers. This is a fact that has to meet complexity thinking, comprising interdisciplinary as the exchange of cooperation between disciplines ${ }^{(12)}$.

Complexity thinking also proposes transdisciplinary as cognitive schemes that have the ability to pervade the disciplines ${ }^{(12)}$. Such thinking seems to be already taking place in the group, although without the reflection of teachers, as they mentioned as potential knowledge exchange between teachers and family caregivers. It was evident the link between scientific knowledge and common sense, acquired through life experiences in daily care to elderly person with Alzheimer's disease.

Participants of this study mentioned some weaknesses that hinder the activities, highlighting the ignorance of people about Alzheimer's disease and the lack of guidance from the family; the non-acceptance of the disease by people and fear of the unknown. In this regard, the complexity thinking brings reflection that each mind is endowed of potential for himself (self-deception), which is a permanent source of errors and illusions. It also presents that in human beings, the system of ideas is not only subject to error, but also protects the errors and illusions contained therein, because it is the organizing logic of the system of ideas resist information that does not suit them or cannot assimilate ${ }^{(15)}$.

Regarding the opportunities of the group, the teachers showed the possibility of a greater knowledge about the disease, the link between theory and practice, building different look for the elderly person with Alzheimer's disease and the caregiver in their different dimensions. These dimensions are given from the perspective of complexity, as individual, social, biological, economic and psychological, because as a human being, man is biological and cultural at the same time ${ }^{(10)}$.

This view at the various human dimensions is needed when it is thought of care from the perspective of complexity, because unlike a simple system, care, in this view, has many parts/dimensions that interact with each other. In systemic process, in which the different parts/dimensions are the whole, the movement is generated and boosted by how they interact. The more intense the relationships, interactions and associations in the care process, the greater will be the possibilities of creative dialogue and therefore the depth and quality of care ${ }^{(16)}$.

For teachers, it is important and necessary 
to expand the knowledge produced in the group to the extent of other people living in the context of Alzheimer's disease and to society as a whole, breaking stigma and prejudice. The teachers of this study indicated that the attendance of family/ caregivers in the group is a threat to the existence of it. This difficulty may be linked to the fact that family members have limited time, since the elderly person with Alzheimer's disease requires constant attention and care $^{(17-18)}$. It is also related to the non-acceptance of the disease, which generates disorder in the familiar surroundings.

In this regard, it is good to reflect in the strategies being used by the group to sensitize these people. Complexity thinking perceives the strategy as the art of using and integrating information arising in action, forming performance schemes, in order to gather as much certainty to recognize/live with the uncertainties $^{(10)}$. Thus, professionals need to promote knowledge of family/caregivers who attend the group to form the action scheme, so the uncertainty in search of a better awareness of family/caregivers as parts and society as a whole can be faced.

The value of this knowledge is already a reality experienced in the group, through the interaction between teachers, students and family/caregivers. Perhaps what is needed is to investigate what the possible factors that hinder the attendance of family/caregivers in the group, so they can promote interventions directed to the difficulties. Such difficulties, in view of the complexity, can be seen as disorders of the elderly lived in the family context as result of Alzheimer's disease.

In this case, the interventions are not meant to stop the disorder but help to understand a new order through (re)organizational processes, allowing relatives/caregivers attending the group. In this sense, it is up to professionals to address order and disorder as antagonistic and complementary phenomena ${ }^{(12,16)}$, since all disorder automatically lead to a new order that can be facilitated if family members have this understanding ${ }^{(10)}$. In this process, the group has a vital importance as it articulates the different social actors and thus has greater potential for sensitization.

By the view of the complexity, nothing is lost, but everything is possible and subject to a new organization. Thus, understanding the meaning of Alzheimer's disease from the support group means to accept the process of order, disorder and organization that go parallel in an effort to survive. It means to understand and accept the conflict as something inherent to human existence and as a possibility for new opportunities, even if initially misunderstood to the eyes of simplification.

\section{Final Considerations}

From the realization of this study, it was possible to know the reality experienced by a group of health care teachers in support group for family/ caregivers, considering the difficulties/weaknesses, potentials/strengths, opportunities and challenges or threats.

As the main frailty and weakness, the teachers mentioned the difficulty in raising awareness of the participants about Alzheimer's disease. As potential and strengths, they highlighted the interdisciplinary approach in the guidelines, the exchange of knowledge. Regarding the opportunities, they said the group gives opportunity (or)acquire/search for more knowledge. They also said the expansion/ socialization of knowledge about Alzheimer's disease is a still existing challenge and the lack of attendance of family/caregivers in the group is a threat to the existence of the group.

The study allowed noticing that the presence of the disorder is constant in the activity developed by teachers participating in the group. This disorder appears in the reports as weaknesses, challenges, threats to constantly entice professionals to seek 
new ways to (re)organization for the realization of its activities in search of the best way to guide and promote the care of family caregivers.

This study has limitations as any qualitative study, which by nature does not intend to generalize the results. Thus, it stands out the impossibility of reproducing the data presented here if the method is applied in another reality or scenario, since they represent unique experiences of a group of teachers. Some points have contributed to realization of the study, highlighting the data collection method through Focus Groups and analysis by Strategic Focal analysis that extended discussions and at the same time, provided the necessary deepening of the data to qualitative research.

In addition, there is the reference used that allowed working in the context of Alzheimer's disease, not seeking to end all existing disorder, but aiming (re)organization processes from disorder. These factors attributed to this study, characteristics that make contributing to innovation and rethinking of care practices of health professionals/Nurses.

From the data presented, we suggest more studies using systemic references that realize that the complete disorder exclusion cannot be possible but understand it as a process and from that understanding, consciously (re)organize it is a possible way to accomplish new order.

\section{Collaborations}

Ilha S and Backes DS contributed to the conception and design or analysis and interpretation of data; writing of the article or revising it critically for important intellectual content and final approval of the version to be published. Santos SSC, GautérioAbreu DP, Zamberlan C and Blasi TC contributed to the writing the article or critical review of important intellectual content final approval of the version to be published.

\section{References}

1. Silva CF, Passos VMA, Barreto SM. Frequência e repercussão da sobrecarga de cuidadoras familiares de idosos com demência. Rev Bras Geriatr Gerontol. 2012; 15(4):707-31.

2. Oliveira APP, Caldana RHL. As repercussões do cuidado na vida do cuidador familiar do idoso com demência de Alzheimer. Saúde Soc. 2012; 21(3):675-85.

3. Seima MD, Lenardt MH, Caldas CP. Relação no cuidado entre o cuidador familiar e o idoso com Alzheimer. Rev Bras Enferm. 2014; 67(2):233-40.

4. Ilha S, Backes DS. (Re)Organizacão familiar no contexto da doença de Alzheimer em idosos: estudo descritivo-exploratório. Online Braz J Nurs. [Internet]. 2014 [citado 2015 mar. 13]; 13(sup 1):478-81. Disponível em: http://www. objnursing.uff.br/index.php/nursing/article/ viewFile/4963/pdf_286

5. Ilha S, Zamberlan C, Nicola GDO, Araújo AS, Backes DS. Refletindo acerca da doença de Alzheimer no contexto familiar do idoso: implicações para a enfermagem. Rev Enferm Cent-Oeste Min. 2014; 4(1):1057-65.

6. Holanda ITA, Ponte KMA, Pinheiro MCD. Idosos com Alzheimer: um estudo descritivo. Rev Rene. 2012; 13(3):582-9.

7. Ilha S, Zamberlan C, Gehlen MH, Dias MV, Nicola GDO, Backes DS. Qualidade de vida do familiar cuidador de idosos com Alzheimer: contribuição de um projeto de extensão. Cogitare Enferm. 2012; 17(2):270-6.

8. Barbosa RL, Morais JM, Resck ZMR, Dázio EMR. 0 cuidador domiciliar de paciente idoso com mal de Alzheimer. Rev Rene. 2012; 13(5):1191-6.

9. Borghi AC, Castro VC, Marcon SS, Carreira L. Overload of families taking care of elderly people with Alzheimer's disease: a comparative study. Rev Latino-Am Enfermagem. 2013; 21(3):876-83.

10. Morin E. Ciência com consciência. Rio de Janeiro: Bertrand Brasil; 2010.

11. Pope $C$, Mays N. Pesquisa qualitativa na atenção à saúde. Porto Alegre: Artmed; 2009. 
12. Morin E. A Cabeça bem-feita: repensar a reforma, reformar o pensamento. 17aㅡ ed. Rio de Janeiro: Bertrand Brasil; 2010.

13. Backes DS, Colomé JS, Erdmann RH, Lunardi VL. Grupo focal como técnica de coleta e análise de dados em pesquisas qualitativas. Mundo Saúde. 2011; 35(4):438-42.

14. Morin E. Introdução ao pensamento complexo. 4⿳亠丷a ed. Porto Alegre: Sulina; 2011.

15. Morin E. Os sete saberes necessários à educação do futuro. 2a ed. São Paulo: Cortez; Brasília: UNESCO; 2011.
16. Backes DS, Zamberlan C, Freitas HB, Colomé J, Souza MT, Costenaro RS. Del cuidado previsible al cuidado complejo de enfermeira. Enferm Global. 2014; 13(36):282-8.

17. Diel L, Forster LMK, Kochhann R, Chaves MLF. Sociodemographic profile and level of burden of dementia patients' caregivers who participate in a support group. Dement Neuropsychol. 2010; 4(3):232-7.

18. Morais HCC, Soares AMG, Oliveira ARS, Carvalho CML, Silva MJ, Araujo TL. Burden and modifications in life from the perspective of caregivers for patients after stroke. Rev Latino-Am Enfermagem. 2012; 20(5):944-53. 